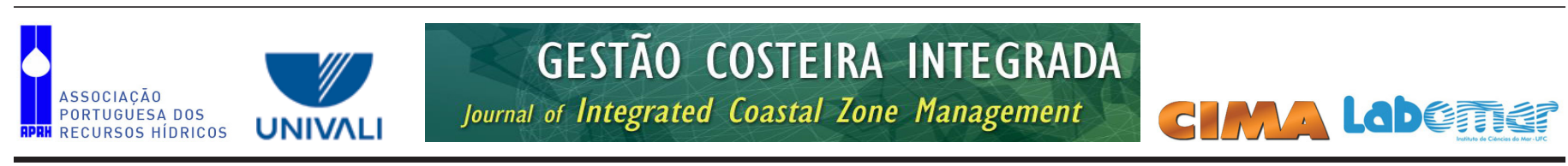

http://www.aprh.pt/rgci/pdf/rgci-417_Costa.pdf | DOI:10.5894/rgci417

\title{
The use of an Estuarine System (Mondego estuary, Portugal) as Didactic Tool to incorporate Education for Sustainable Development into School Curricula *
}

\section{O uso de um sistema estuarino (Estuário do Mondego) como ferramenta didáctica na incorporção da Educação para o Desenvolvimento Sustentável nos curricula escolares}

\author{
Sónia Costa ${ }^{\circledR, 1}$, Miguel Ângelo Pardal ${ }^{1}$, Ulisses Miranda Azeiteiro ${ }^{1,2}$
}

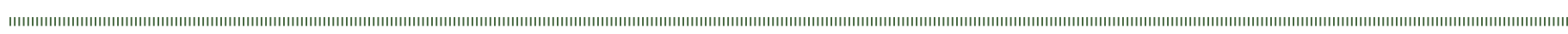

\begin{abstract}
The present paper reviews and discusses the use of the Mondego estuary (Portugal) ecosystem as educational tool for science and environmental teachers/educators. The Mondego estuary is a coastal area of acknowledged high socioeconomic and environmental value (National Ecological Reserve, Important Bird Area and RAMSAR site) whose characteristics (e.g. two distinct subsystems with different physicochemical and ecological characteristics, strong environmental gradients, and anthropogenic pressures) have been used for educational purposes. However, besides the vast available scientific output focused in the Mondego estuary, few had the focal point in its pedagogical potentialities (were only published three MSc dissertations and two book chapters in books of Environmental Education incorporating teaching strategies to approach issues, behind different educational perspectives). The Mondego estuary is presented here as an ecosystem that can be used for educational purposes related to ecology, conservation biology, and sustainability in the coastal zone. In order to use the Mondego estuarine system under an educational framework, some examples of tools to address the pedagogical potentialities, like interpretative routes, analysis of scientific texts, and teachers training programs are presented.
\end{abstract}

Keywords: Mondego estuary, pedagogy and curriculum, environment, sustainability.

\section{RESUMO}

O presente trabalho revê e discute o potencial do ecossistema estuário do Mondego (Portugal) como ferramenta educacional para professores/ educadores em ciências e para a sustentabilidade. Este estuário é uma área costeira de reconhecido valor socioeconómico e ambiental (Reserva Ecológica Nacional, Área Importante para as Aves e sitio Ramsar), cujas características (por exemplo, dois subsistemas distintos, com diferentes características físico-químicas e ecológicas, fortes gradientes ambientais e pressão antrópica) apresentam elevado potencial educativo. Contudo, apesar da vasta produçáo científica disponivel focada no estuário do Mondego, poucos trabalhos tiveram o enfoque nas suas potencialidades pedagógicas (apenas foram publicadas três dissertaçôes de mestrado e dois capitulos em livros de Educação Ambiental, incorporando estratégias de ensino para abordar questóes relacionadas com este ecossistema estuarino, sob diferentes perspectivas educacionais). O estuário do Mondego é apresentado aqui como um ecossistema que pode ser usado com objetivos educacionais relacionados com a ecologia, biologia da conservação e sustentabilidade na zona costeira. De modo a usar o estuário do Mondego sob um formato educational sáo apresentados alguns exemplos de ferramentas para desenvolver as suas potencialidades pedagógicas, tal como percursos interpretativos, análise de textos científicos e programas de formação de professores.

Palavras-chave: Estuário do Mondego, pedagogia e curriculum, ambiente, sutentabilidade.

@- Corresponding author

1 - CEF - Centro de Ecologia Funcional, Departamento de Ciências da Vida, Universidade de Coimbra, Apartado 3046, 3001-401 Coimbra, Portugal. e-mails: soniacosta@ci.uc. pt; mpardal@ci.uc.pt; ulisses@uab.pt

2 - Universidade Aberta. Departamento de Ciências e Tecnologia. Palácio Ceia. Rua da Escola Politécnica, 141 - $147.1269-001$ Lisboa, Portugal

* Submission: December 15th, 2012; Evaluation: February 08th, 2013; Reception of revised manuscript: May 14thX, 2013; Accepted: May 20th, 2013; Available on-line: 7 June 2013 


\section{INTRODUCTION}

The multiple stressors affecting the coastal zones together with their economic and social roles brings the attention of researchers, policy makers, and general public to this environmental sensitive areas. In this sense, its conservation constitutes one of the present subjects of concern and raised the need of its integrated management (Gomes, 2007).

From the wide geomorphological diversity of coastlines, estuaries are areas of key environmental relevance (Costanza et al., 1997; Barbier et al., 2011). It has been intensely demonstrated the role of estuaries for life in the oceans, especially coastal platforms, serving as local of breeding, spawning and growth of many marine species (Cabral et al., 2007; Martinho et al., 2007, 2012), migratory routes of avifauna (Lourenço et al., 2008; Burton et al., 2010) and habitat use for resident species (Baptista et al., 2010; Nyitrai et al., 2012). The estuaries were always areas of high human occupation. Consequently, the population growth around them has been accompanied by some degree of anthropogenic disturbance including resources depletion and pollution (Kennish et al., 2002).

The Mondego estuary, located in the Atlantic coast of Portugal, is a pertinent example both of the range of pressures and impacts on coastal wetlands and of an area that has been focus of attention by researchers and policy makers. There is a vast multidisciplinary published science in the literature (Costa et al., this volume), that should support reasoned management decisions/actions in the Mondego estuary.

It is recognized that biodiversity conservation and sustainable management requires sound scientific knowledge. Nevertheless, the translation of ecological/ scientific knowledge into accurate and serviceable forms for policy makers, management, or educational purposes is often delayed (EVC, 2004). The knowledge resulting from research focused in the Mondego estuarine system that supported remediation measures to mitigate environmental problems (Costa et al., this volume) is an example of such practices. The referred multidisciplinary of the Mondego scientific knowledge could be additionally used for educational aims, including Environmental Education (EE) and Education for Sustainable Development (ESD).

More emphasis is needed to be placed on the importance of natural resources, biodiversity conservation, and ecosystem services in the teaching of ESD. Assuming that perspective, the $\mathrm{EE}$ is becoming an integral part of the education of any country's youth. In Portugal, the educational guidelines also presume the inclusion of environmental and nature conservation aspects in school curricula and textbooks.

Because a sustainable coastal management must involve decision-making processes of strongly public participation that implies all stakeholders, especially the local population (MAOTDR, 2007), the citizen involvement is crucial. To achieve this intend it becomes urgent to develop awareness initiatives, information and promotion of skills for action (environmental literacy). Only environmentally literate citizens can take conscientious and informed opinions (EVC, 2004; Azeiteiro et al., 2004; Almeida \& Azeiteiro, 2011; Almeida et al., 2012).

For educating environmentally literate citizens, one of the skills postulated by the Portuguese National Curriculum of Basic Education ${ }^{1}$ (DEB, 2001a) to be achieved by the end of Basic Education is the construction of an ecological consciousness conducive to the recovery and preservation of natural and cultural heritage. In this sense, is important that students understand the relationship between science and daily life (Pato et al., 2007; Almeida et al., 2012; Costa et al., 2012). This achievement is possible through the participation in practical activities based on problem solving and developing critical thinking and reasoning. Consequently, those students will become informed adults citizens that will be able to deal with the environmental problems faced by society. In all that process the teachers/educators role is crucial because they can increase the students' opportunities to gain knowledge, form positive attitudes about nature, and practice action skills (Chawla \& Cushing, 2007).

In this line of reasoning, the purposes of the present study were: a) to review the existent literature with pedagogical application focused on Mondego estuary; c) to explore and discuss other potentialities of the Mondego estuary research as a didactic tool. It is our intent that the use of an ecosystem to develop activities of Science Education, EE and EDS could be an important way to achieve some of the aims of the sustainability.

\section{MONDEGO ESTUARY}

The Mondego estuary (Fig. 1) is located in the western of Portugal $\left(40^{\circ} 08^{\prime} \mathrm{N}, 8^{\circ} 50^{\prime} \mathrm{W}\right)$. About $6.5 \mathrm{~km}$ from the mouth is divided into two arms (North and South) delimiting the Murraceira Island. The two arms represent distinct subsystems with very different characteristics. The North arm is deeper and more hydrodynamic. It corresponds to the navigation channel and supports the Figueira da Foz harbour. The South arm is shallower and covered by extensive intertidal mudflats.

The estuary has an important regional socio-economic value providing several goods and services for the population. It supports industrial activities, mercantile and fishing harbours, aquacultures, salt-works, and agricultural areas (Fig. 1). As result of those different uses, the Mondego estuarine system has undergone intense anthropogenic pressures and several hydromorphological transformations over the last decades (Marques et al., 2007a). Those constrains induced progressive decline in the estuarine environmental quality (Marques et al., 1997; Pardal et al., 2000, 2004; Dolbeth et al., 2003). The interventions comprised the margins' regularization in the harbour area and navigation channel's depth increase in the river mouth area; margins' regularization between arms separation point

\footnotetext{
1 - In Portugal the pre-higher education last for twelve years. The first nine years is known as the Basic Education and are divided into three stages of four, two and three years respectively. The stages are $1^{\text {st }}, 2^{\text {nd }}$ and $3^{\text {rd }}$ Cycle, respectively. The Secondary Education consists of a three-year cycle after basic education. From 2012/13 the Secondary school was compulsory. Following the secondary school the students could ingress in the Higher School that actually follows the Bologna process with a first cycle of study (graduation), plus a second cycle conferring the master's degree.
} 
and harbour areas, diminishing river width, and narrowing the communication between arms. The interruption of the communication between the two estuarine arms lead to a drastic reduction of water circulation through the South arm leading to water residence time increase in this area. As consequence, there was an increasing of turbidity and an excess of nutrients that resulted in the eutrophication of the South arm (Patrício et al., 2006; Dolbeth et al., 2007; Leston et al., 2008). Those features resulted in the impoverishment of the ecosystem. It was registered a replacement of seagrass coverage by opportunistic macroalgae, increased degradation of water quality, a decline of species diversity and secondary production as well as decline in herbivores and an increase in detritivores (Pardal et al., 2004; Cardoso et al., 2005; 2007; 2008; Verdelhos et al., 2005; Dolbeth et al., 2008). In order to improve its ecological status the system has been target of restoration plans since the 1990s. In 1997/98 were implemented several mitigation measures (the physical protection of the seagrass area from human disturbance; the change of the discharge location of Pranto River flows; the enlarging of the connection between the two arms) (Cardoso et al., 2005, 2008; Duarte et al., 2008), followed by a more intense intervention undertaken in 2006 consisting in the total re-establishment of the upstream connection between the two arms (Falcão et al., 2011; Veríssimo et al., 2012). Those actions improved the hydrodynamic conditions in the South arm and diverted the nutrient loading. In addition to the anthropogenic pressures, the estuary has also been affected by the occurrence of natural extreme climatic events in the last years (Marques et al., 2007b; Martinho et al., 2007; Cardoso et al., 2008; Grilo et al., 2010; Dolbeth et al., 2011). As result there were recorded changes in the species distribution, dynamics, and changes in its structure and composition (Marques et al., 2007b; Baptista et al., 2010; Grilo et al., 2011; Nyitrai et al., 2012).

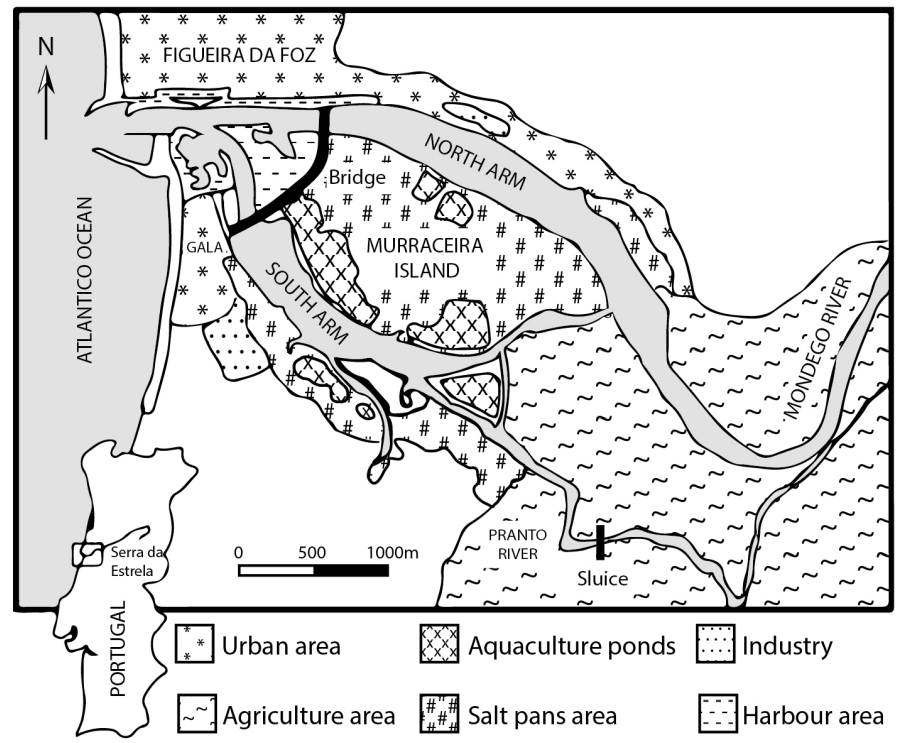

Figure 1. Mondego estuary (Portugal). Location of functional areas around the estuary (adapted from Ribeiro, 2005).

Figura 1. Estuário do Mondego (Portugal). Localização das áreas funcionais adjacantes ao estuário (adaptado de Ribeiro, 2005).

\section{DIDACTIC POTENTIALITIES OF THE MONDEGO ESTUARY}

The Mondego estuary is an area of high environmental value (National Ecological Reserve, Important Bird Area (PT039), and RAMSAR site $n^{\circ}$. 1617) whose characteristics (e.g. two distinct subsystems with different physicochemical and ecological characteristics, strong environmental gradients, and anthropogenic pressures) present clear educational potentialities allowing recognizing the role of different factors in the ecosystem dynamics. This coastal zone is particularly suitable for the creation and implementation of didactic-pedagogical activities, not only for courses of High School but also for the teaching of Ecology in the Basic and Secondary School (integrated, for instance, in the curriculum of the discipline of Natural Sciences and Biology, but also for transdisciplinarity with the other disciplines). It is also appropriated under the EE, EDS, and Education for Citizenship, for the resident population in their surrounding and for students and science teachers/educators. In this context, to offer a range of educational activities to develop investigation and problem-solving skills, the discovery of ecological principles and forward environmental awareness based on Mondego estuarine ecosystem seems to be an important contribute to the development of informed, reasoned and active citizens.

\subsection{Review on literature published concerning pedagogical approaches about the Mondego estuarine ecosystem}

The research on the Mondego estuary has produced significant insights into complex ecological interactions happening in the system (Costa et al., this volume). Nevertheless, besides the vast scientific production already published, few had the focal point in its pedagogical potentialities. Till the moment, to our knowledge, only 3 MSc dissertations (Carvalho, 2003; Costa, 2006; Luís, 2006) and 2 book chapter (Carvalho et al., 2007; Costa et al., 2008), had the center in a didactic approach of that system, behind different perspectives.

One of the studies (Carvalho, 2003) consisted in the elaboration of a set of activities to develop with students of $10^{\text {th }}$ grade in the Biology classes. The author proposed an investigative route of experimental nature using the intertidal habitat as support. For planning the learning activities were determinants the heuristic resources constructed (Gowin's $\mathrm{V}$ and conceptual maps), from which was systematized the experimental route using explanatory worksheets. The didactical process included several steps that students must to follow: to prepare an oral presentation about the estuary characterization after bibliographic research; to collect water and intertidal biota samples; to perform the water analysis; to preserve, identify and quantify the macrofauna; to calculate the specific richness (Margalef indices); to discuss about the results and to take conclusions.

A second didactic work was drawn by Luís (2006). The author implemented an investigative project with students of the $8^{\text {th }}$ grade integrated in the discipline Natural Sciences and related to the syllabus topic Ecosystems. The first part consisted of field trips in the Figueira da Foz coastal 
location, including the Mondego estuary. The students were supposed to analyse its main physical characteristics and the predominant macroinvertebrates on a rocky area of the estuary. The author, in the end of the activities, applied a questionnaire to the students allowing the identification of the main difficulties faced by them. They were the collection of material in the shores, and walk on the rocks.

The third project with pedagogical applicability was developed by Costa (2006) that proposed some activities to implement with students of $12^{\text {th }}$ year (secondary school). The activities were directed to fishing resources, aquaculture and food quality, using a database on growth and nutritional composition of wild and farmed seabass (Dicentrarchus labrax), collected in the Mondego estuary and in a fish farm located in the Murraceira Island. Among other tasks, the students should analyse the results of wild Mondego and farmed seabass concerning growth and nutritional composition in order to calculate several parameters and to compare the results, and to take conclusions.

In the above works the teachers may find theoretical support to the teaching-learning process, auxiliary teaching materials (worksheets and experimental protocols), and methodological suggestions aiming to address the difficulties that teachers encounter in the fulfillment of innovative educational practices.

Other pedagogical approach developed in the Mondego estuary was integrated in the project of Education for Sustainability named "Biologia no Verão", created by "Ciência Viva" program from the National Agency for Scientific and Technological Culture of Portugal. Between 2001 and 2007, in the summer months, the participants registered in the program went to the estuary where they observed, collected and identified the species inhabiting there, from algae to birds. The activities aimed to make known the estuarine species and habitats in order to stimulate the interest for science and aware for habitats preservation.

\subsection{General guidelines to develop the didactic potential of Mondego estuarine ecosystem}

Besides the relevant activities already realized based on the Mondego estuarine ecosystem, we are convinced that many others could be idealized and developed with didacticpedagogical purposes. A consistent scientific approach coupled with a didactic framework is the best way to engage the student's mind, increasing interest for science, and develop respect for the nature. In Education for Science, and in the Education for Sustainability the relevance of using situations and current issues, contextualize the learning, and articulate them with prior knowledge has been highlighted by several investigators (Wellington \& Osborne, 2001; Wellington, 2002; Roth \& Lee, 2004; Hofstein et al., 2005; Rivet \& Krajcik, 2008). So, we think that could be very interesting to transform the vast scientific outputs of the Mondego estuary in a set of pedagogical activities/tools/actions, directed to school groups and/or to the general public. The general idea that over the years the ecologists (and scientist in general) have created a huge knowledge base, but they do not always advertise its availability or know how to present it to nonscientists in a comprehendible form (EVC, 2004), should be reversed.
In educational terms, the case of the Mondego estuary can be approached from multiple points of view, according to the targeted audience. The extent and quality of data available about the system turns it appropriated to be converted into didactic resources. In the disciplines of Natural Sciences for the Basic Education and in the Biology of Secondary Education programs there are conceptual subjects that might be covered by various topics of an estuarine system (DEB, 2001a, b; DES, 2001, 2003, 2004). The educational materials eventually produced could include various topics of the Mondego estuary, because all have been object of scientific research (e.g. biodiversity, water quality, toxicology, environmental preservation, geology), and only a small part of it was presented in the pedagogical actions already developed. It is desirable that activities induce both students and teachers/educators greater perception of the estuarine environmental vulnerability to the anthropogenic activity, either directly, through contamination by pollutants or indirectly through climate change (i.e. global warming), but also highlight its primary and secondary productivity, variability of habitats, and particularities of some estuarine species. Either, the structure and dynamics of the estuarine ecosystem and the interdependence between the biotic community and the abiotic factors are topics very interesting to explore pedagogically. The activities could advance, for instance on the biodiversity in a wide-range or choose a case study habitat, among many other possibilities. In this respect, given the complexity of the Mondego estuary, numerous issues can be raised leading to the hypothesis formulation and subsequent research planning by students, such as: What is the influence of human activities on water quality of the estuary?; What is the effect of dredging on macrobenthic community of the North arm?; What are the effects of extreme events on the communities?; How to avoid the disappearance of Zostera noltii beds?

Recreational/educational environmental interpretation activities using and valuing the historical and environmental heritage of the Mondego estuary could be achieved directly in loco and/or in the schools (classroom or laboratories). In the scope of that ecosystem, the implementation of field and laboratorial activities and/or classroom practical exercises provides opportunities for different types of learning outcomes. The outdoor activities, for example, are extremely important to promote meaningful science learning in students (Almeida et al., 2012; Boaventura et al., 2013). Several studies make reference to the importance of field trips for learning and for improve the behaviours and attitudes toward the environment (Lisowski \& Disinger, 1991; Orion \& Hofstein, 1991; 1994; Manzanal et al., 1999; Abrahams \& Millar, 2008; Lei et al., 2010) . Fieldwork enables the learner to interpret the complex framework of ecological relationships, with the proviso that the elements should be chosen carefully so that the learner is not confused and overwhelmed by the variety of questions that the ecosystem raises (Manzanal et al., 1999). All activities in the field should therefore be carefully prepared.

As mentioned above, the approach to follow pedagogical objectives concerning the Mondego estuary could be diverse. However, it is essential for its elaboration to keep in mind the guidelines recommended by the Portuguese educational 
policy documents. In this context, the promotion of active learning, and the use of laboratorial and field work is particularly emphasized in the programs of Sciences. In fact, the Curriculum Guidelines for Physical and Natural Sciences of the 3rd cycle (DEB, 2001b), the Program of Biology and Geology of $10^{\text {th }}$ and $11^{\text {th }}$ grade (DES, 2001b), Biology of $12^{\text {th }}$ grade (DES, 2004a) and Geology of $12^{\text {th }}$ grade (DES, 2004b) highlight the need to potentiate activities of small inquiry and investigation, including, preferably, the use of these two tools (DES, 2001b). The objective is to support the clarification of previous conceptions of students, the formulation of hypothesis, the planning and eventual implementation of activities, the collection and analysis of data. It is aimed, primarily, to promote an integrated view of science, interrelating technology, society and environment to produce valid knowledge (DEB, 2001a, b; DES, 2001, 2003, 2004). The teaching resources should have the goal of promoting the development of skills, values, attitudes, and behaviours to expand the scientific knowledge of the students, i.e. to increase its scientific literacy. This objective is easier to achieve by linking the scientific knowledge with quotidian worries and stimulating the student's curiosity.

It should be added that the environmental issues are part of several programs areas/subjects of different levels of education in Portugal and, in addition, taking into account the transversal theme "environment", this can be treated in all curricular areas since school decides to develop the environmental dimension in their curriculum project (Gomes, 2001).

\subsection{Examples of activities to use the Mondego estuary as didactic tool}

The Mondego estuary can be addressed under the referred didactical guidelines through different ways developing and using diverse pedagogical tools. Thus, field trips, interpretive routes, worksheets, scientific texts analysis, educational games, multimedia presentations (some already developed in the MSc dissertations mentioned above), and workshops are resources that could be developed/constructed based in the available scientific reports of the estuary. The transformation of scientific knowledge into accessible information and easy to understand by students (or by population in general) is very useful in the teaching/learning science process, but also in the educational process for sustainability. However, teachers/ educators need increased access to ecological knowledge in useful formats, as well as to the latest advances in ecology education theory and practice (EVC, 2004) in order to improve their teaching. Parallel to the ecology concepts, it is either extremely important highlight the EE and EDS which should be part of the teachers/educators functions.

A very interesting didactic tool used in $\mathrm{EE}$ is the interpretative route. According to Fernandes (1983), an interpretative route is a guided or self-guided tour arranged through urban or rural areas where there are facilities in order to study directly the interrelations of the environmental constituents leading to a better understand of the local. They must be specifically designed so that participants learn to become aware of the natural systems of the region (Oliveira, 2001). In this framework, Mondego estuary presents a prime location for conducting interpretative routes. Moreover, the municipality of Figueira da Foz has defined a pedestrian route in the estuary, designated "Salines Route" which could be explored by school groups. When the interpretative routes are organized to schools, auxiliary material should be elaborated, like scripts to students and teachers. The teacher script must be a detailed document about the location including a mapping of the local, detailed description of the route, particularities about the geological, biological, and cultural landscapes of places to visit, the elements fauna and flora of most frequent observation zone and, if possible illustrations (e.g. photograph or pictures with the most important aspects to highlight and to identify) (Santos \& Guedes, 1999). For the Mondego estuary, it could be included a map like the one presented in the figure 1, a list of the species that use the Mondego estuary as residence, nursery or migration route, summary information about the aquacultures and saltworks. The student script should include the same information as the teacher one but more resumed. Furthermore, the interpretative routes must be followed by worksheets to be filled by the students during the field trip including, among others, a series of questions posed on the various stopping points. The interpretative route could be particularly useful to the schools located in the Figueira da Foz, but also for schools from other regions as part of a study visit, or for tourists. The interpretative routes developing could be part of a bigger project like the implementation of an environmental interpretation center with an educational project documented and disclosed, based on scientific research, with one team stable and professionalized, characteristics of the equipments for EE (Carvalho et al., 2011) could be also a very interesting way to achieve the aim to use the Mondego estuary as a educational tool. Those kinds of environmental education centers have an important role in different points. They collaborate in the training of educational, technicians and policy makers professionals. Usually, they are stable references for the local community, for international organizations and institutions. Either, they have continuity in time allowing develop long term projects and they generate and streamline other programs, resources and materials (Serantes, 2008; Carvalho et al., 2011).

Another way of use the Mondego estuary as educational resource is the analysis of published papers in classes, mainly with the older students. Faced with the new conceptions of education, and the desired environmental competencies and literacy leading to a generation of informed and critical citizens in society (Azeiteiro et al., 2004; Almeida et al., 2012), the science texts could constitute an important teaching resource (Rocha, 2012). This resource can be used as a complement to the traditional teaching materials that facilitates a close relationship between science and society (van Week et al., 2007). So, it is important to prepare the students to analyse the science texts, particularly the ones published in the media. One goal of science communication is precisely to make scientific knowledge accessible to the public, creating a bridge between the world of science and society (Mora, 2003). The popularization of science and technology is needed for the cultural development. Beyond the publications on scientific journals, some research on Mondego was focus of publication in the media, and 
those texts could be either used at class. The information transmitted by media is usually an efficient form of capture the attention to nature conservation problems (Rosalino $\&$ Rosalino, 2012).

With the new curricular proposals oriented towards Education for Sustainability, new demands are placed on teachers. However, these do not always demonstrate that they have the necessary training in this area (Nunes et al., 2009). Parallels, the educational innovation depends directly on the training of teachers (Marques, 2004). To use the Mondego estuary as educational resource is fundamental to have trained and motivated teachers. It will be required its improved literacy about ecology and ecological sustainability. Both in formal or non-formal education, the level of knowledge and enthusiasm of teachers are key factors in encouraging students (Arima et al., 2005). The teachers have the ability to awaken in the student a desire to have an active and vital role in maintaining and/or preserve environment as well as the interest for science. So, the potentiality of Mondego estuary as didactic tool passes inevitably through the continuous teacher training. The training should focus on the planning and development of activities with teachers connected to their needs (Pedrosa \& Mateus, 2000; Marques, 2004). In this sense, it is essential to improve the knowledge of teachers over the Mondego estuary from several points of view, so they could be able to implement and develop strategies with their students. A training program for teachers of Natural Sciences/Biology, with the purpose of promotion of concepts and practices for the use of laboratory and field activities focused in the Mondego estuarine system and under the EE guidelines could be implemented.

As a last suggestion, and because the internet is nowadays a easy useful method to disclose information, we think that the large knowledge about the Mondego estuarine ecosystem enables the construction of a website to disclose it to the common visitor and provide educational materials/ resources for students and teacher use. It could include the characterization of the various species that inhabit the estuary, the goods and services provided by them, the threats that affect it, among other possibilities.

\section{FINAL REMARKS}

The Mondego estuary and the research performed so far have been very important for science and to support management decisions (Costa et al., this volume), but it is also valuable for didactic purposes. This estuary, despite having been studied in a multidisciplinary perspective over the last three decades, mainly by researchers from the University of Coimbra was, until now, from our point of view, target of few pedagogical projects. In future, we think more work is needed to be developed on this context, because there is little educational material available on the Mondego estuary or the existing material is not well uncovered. In short, the role of research teams in the development of the Education for the Sustainability is very important, mainly through the development of pedagogical projects to implement among young students. In fact, it is needed not only to reinforce research, but perhaps more importantly, it is needed to communicate science much more effectively than has been made (EVC, 2004). Since social values are considered more important than environmental conservation, Portuguese conservation programs should be directed towards persuading students that environmental issues are also closely tied to human survival (Rosalino \& Rosalino, 2012). The key for environmental preservation relies in the correct scientific information given to the population and in the training of teachers and students.

\section{REFERENCES}

Almeida, F.I.R.G.; Azeiteiro, U.M. (2011) - Literacia Ambiental no Ensino Secundário - O caso da Escola Secundária Dr Manuel Candelas Gonçalves. Captar (ISSN: 1647-323X), 3(2):45-68, Universidade de Aveiro, Aveiro, Portugal. http://captar.web.ua.pt/ media/\%5B4\%5DAlmeida\%20e\%20Azeiteiro_ CAPTar.pdf

Almeida, A.S.; Gonçalves, A.M.; Azeiteiro, U.M.; Gonçalves, F. (2012) - Effectiveness of outdoor practices on environmental sustainability, In: F., Gonçalves, R. Pereira, W. Leal-Filho \& U.M. Azeiteiro (eds.), Contributions to the UN Decade of Education for Sustainable Development, pp.213-234, Peter Lang. ISBN: 978-3653016314.

Alves, F.; Araújo, M.J.; Azeiteiro, U. (2012) - Cidadania ambiental e participação: o diálogo e articulação entre distintos saberes-poderes. Saúde em Debate (ISSN: 01031104), 36:46-54, Revista do Centro Brasileiro de Estudos de Saúde (CEBES), Rio de Janeiro, RJ, Brasil. Available at http://www.cebes.org.br/media/File/Revista_Saúde_ em_Debate\%20-\%20Rio+20.pdf

Arima, A.; Konaré, A.O.; Lindberg, C.; Rockefeller, S. (2005) - United Nations Decade of Education for Sustainable Development 2005-2014. International Implementation Scheme, Draft. 52p., UNESCO, Paris, France. http:// unesdoc.unesco.org/images/0013/001399/139937e.pdf

Azeiteiro, U.M. (2004) - Assessment of an Environmental Education Action about Water Resources Conservation. In W. Leal-Filho \& M. Littledyke (eds), International Perspectives in Environmental Education, pp.209-222, Peter Lang. ISBN: 978-3631522967.

Baptista, J.; Martinho, F.; Dolbeth, M.; Viegas, I.; Cabral, H.; Pardal, M. (2010) - Effects of freshwater flow on the fish assemblage of the Mondego estuary (Portugal): comparison between drought and non-drought years. Marine and Freshwater Research, 61(4):490-501. DOI: 10.1071/MF09174.

Barbier, E.B.; Sally, D.H.; Kennedy, C.; Kock, E.W.; Stier, A.C.; Silliman, B.R. (2011) - The value of estuarine and coastal ecosystem services. Ecological Monographs (ISSN: 0012-9615), 81(2):169-193. Available at http://www.esajournals.org/doi/pdf/10.1890/10-1510.1.

Boaventura, D.; Faria, C.; Chagas, I.; Galvão, C. (2013) Promoting Science Outdoor Activities for Elementary School Children: contributions from a research laboratory. International Journal of Science Education, 35(5):796814. DOI: 10.1080/09500693.2011.583292.

Burton, N.H.K.; Musgrove, A.J.; Rehfisch, M.M.; Clark, N.A. (2010) - Birds of the Severn Estuary and Bristol Channel: Their current status and key environmental 
issues. Marine Pollution Bulletin, 61(1-3):115-123. DOI: 10.1016/j.marpolbul.2009.12.018.

Cabral, N.H., Vasconcelos, R.P., Vinagre, C., França, S., Fonseca, V., Maia, A., Reis-Santos, P., Lopes, M., Ruano, M., Campos, J., Freitas, V., Santos, P., Costa, M.J. (2007) - Relative importance of estuarine flatfish nurseries along the Portuguese coast. Journal of Sea Research, 57(2-3):209217. DOI: $10.1016 /$ j.seares.2006.08.007.

Cardoso, P.G.; Brandão, A.; Pardal, M.A.; Raffaelli, D.; Marques, J.C. (2005) - Resilience of Hydrobia ulvae populations to anthropogenic and natural disturbances. Marine Ecology Progress Series, 289:191-199. Available at http://www.int-res.com/articles/meps2005/289/ m289p191.pdf.

Cardoso, P.G.; Bankovic, M.; Raffaelli, D.; Pardal, M.A. (2007) - Polychaete assemblages as indicators of habitat recovery in a temperate estuary under eutrophication. Estuarine, Coastal and Shelf Science, 71(1-2):301-308. DOI: 10.1016/j.ecss.2006.08.002.

Cardoso, P.G.; Raffaelli, D., Lillebø, A.I.; Verdelhos, T.; Pardal, M.A. (2008) - The impact of extreme flooding events and anthropogenic stressors on the macrobenthic communities' dynamics. Estuarine, Coastal and Shelf Science, 76(3):553-565. DOI: 10.1016/j. ecss.2007.07.026.

Carvalho, L.M.V.F (2003) - Estudo de um ecossistema estuarino: a diversidade ao longo de um gradiente de salinidade. 191 p., Tese de Mestrado, Universidade de Coimbra. Not published.

Carvalho, L.; Duarte, J.L.; Pardal, M.A. (2007) - O estuário do Rio Mondego: um contributo para a educação ambiental. In: Fernando Gonçalves, Ruth Pereira, Ulisses M. M. Azeiteiro \& Mário J. V. Pereira (eds.), Actividades práticas em ciências e educação ambiental. pp.311-330, Instituto Piaget, Lisboa, Portugal. ISBN: 978-9727718559.

Carvalho, A.M.C. (2011) - Equipamentos para a Educação Ambiental na zona costeira da Euroregião do Eixo Attântico - Das práticas conservacionistas às sociocríticas. Revista da Gestão Costeira Integrada / Journal of Integrated Coastal Zone Management, 11(4):433-450. DOI: 10.5894/rgci264.

Chawla, L.; Cushing, D.F. (2007) - Education for strategic environmental behavior. Environmental Education Research, 13(4):437-452. DOI: 10.1080/13504620701581539

Costa, S.; Azeiteiro, U.M.; Pardal, M. (2013) - The contribution of scientific research for integrated coastal management: The Mondego estuary as study case. Revista da Gestäo Costeira Integrada / Journal of Integrated Coastal Management, 13(2) [this issue]. DOI: 10.5894/rgci391

Costa, S., Gonçalves, A.M.M., Gonçalves, F., Azeiteiro, U.M., Pardal, M.A. (2012) - Developing activities on waste management - an approach to achieve a cleaner environment: In: F. Gonçalves, R. Pereira, W. Leal-Filho \& U.M. Azeiteiro (eds.), Contributions to the UN Decade of Education for Sustainable Development, pp.311-328, Peter Lang. ISBN 978-3631613474.

Costanza, R.; d'Arge, R.; de Groot, R.; Farber, S.; Grasso, M.; Hannon, B.; Limburg, K., Naeem, S.; O’Neill, R.V.; Paruelo, J.; Raskin, R.G.; Sutton, P.; van den Belt, M. (1997) - The value of the world's ecosystem services and natural capital. Nature, 387(6630):253-260. Available at http://www.esd. ornl.gov/benefits_conference/nature_ paper.pdf.

DEB (2001a) - Currículo Nacional do Ensino Básico Competências Essenciais. 240p., Departamento da Educação Básica (DEB), Ministério da Educação, Lisboa, Portugal.

DEB (2001b) - Ciências Físicas e Naturais - Orientaçôes Curriculares para o 30 ciclo do Ensino Básico. 42p., Departamento da Educação Básica (DEB), Ministério da Educação, Lisboa, Portugal.

DES (2001) - Programa de Biologia e Geologia - 10o ano. 97p., Departamento da Educaçáo Básica (DEB), Ministério da Educação, Lisboa, Portugal.

DES (2003) - Programa de Biologia e Geologia - 11 a ano. 48p., Departamento da Educação Básica (DEB), Ministério da Educação, Lisboa, Portugal.

DES (2004) - Programa de Biologia - 120 ano. 40p., Departamento da Educação Básica (DEB), Ministério da Educação, Lisboa, Portugal.

Dolbeth, M.; Pardal, M.A.; Lillebø, A.I.; Azeiteiro, U.; Marques, J.C. (2003) - Short- and long-term effects of eutrophication on the secondary production of an intertidal macrobenthic community. Marine Biology, 143(6):1229-1238. DOI: 10.1007/s00227-003-1133-5.

Dolbeth, M; Martinho, F.; Viegas, I.; Cabral, H.; Pardal, M.A (2008) - Estuarine production of resident and nursery fish species: Conditioning by drought events? Estuarine, Coastal and Shelf Science, 78(1):51-60. DOI: 10.1016/j.ecss.2007.11.021.

Duarte, A.A.L.S.; Vieira, J.M.P.; Neto, J.M.; Pardal, M.A. (2008) - Monitorização da Hidrodinâmica e da Qualidade da Água no Estuário do Rio Mondego. Engenharia Civil (ISSN: 0873-1152), 33:65-74, Universidade do Minho, Guimarães, Portugal. Available at http://www.civil. uminho.pt/revista/n33/Artigo06-Pag65-74.pdf.

EVC - Ecological Visions Committee (2004) - Ecological Science and Sustainability for a Crowded Planet. [Report to the Governing Board of the Ecological Society of America]. 55p., Washington, DC, U.S.A. Available at http://www.esa.org/ecovisions/ppfiles/ EcologicalVisionsReport.pdf

Falcão, J.; Marques, S.C.; Pardal, M.A.; Marques, J.C.; Primo, L.; Azeiteiro, U.M., (2011) - Mesozooplankton structural responses in a shallow temperate estuary following restoration measures. Estuarine, Coastal and Shelf Science, 112:23-30. DOI: 10.1016/j.ecss.2011.06.007

Fernandes, José A. (1983) - Manual de Educação Ambiental. 286p., Comissão Nacional do Ambiente, Lisboa, Portugal.

Gomes, M. (2001) - Educação Ambiental: Guia anotado de recursos. 63p., CCPES/DEB/DES/IIE/IPAMB, Instituto de Inovaçáo Educacional, Lisboa, Portugal. ISBN: 9727830552. Available at http://area.dgidc.min-edu.pt/ inovbasic/biblioteca/cmac01/educ-ambiental-guia.pdf

Gomes, F.V. (2007) - A Gestão da Zona Costeira Portuguesa. Revista da Gestão Costeira Integrada (ISSN: 1646-8872), 7(2):83-95, Lisboa, Portugal. http://www.aprh.pt/rgci/ pdf/rgci7f2_1_velosogomes.pdf

Grilo, T.F.; Cardoso, P.G.; Dolbeth, M.; Bordalo, M.D.; 
Pardal, M.A. (2011) - Effects of extreme climate events on the macrobenthic communities' structure and functioning of a temperate estuary. Marine Pollution Bulletin, 62(2):303-311. DOI: 10.1016/j. marpolbul.2010.10.010.

Kennish,M.J.(2002)-Environmentalthreatsandenvironm ental future of estuaries. Environmental Conservation, 29(1):78-107. DOI: 10.1017/S0376892902000061.

Lei, S. A. (2010) - Field trips in college biology and ecology courses: revisiting benefits and drawbacks. Journal of Instructional Psychology (ISSN: 0094-1956), 37(1):42-48. Available at http://www.freepatentsonline.com/article/ Journal-Instructional-Psychology/224405377.html.

Leston, S., Lillebø, A.I., Pardal, M.A. (2008) - The response of primary producer assemblages to mitigation measures to reduce eutrophication in a temperate estuary. Estuarine Coastal and ShelfScience, 77(4):688-696. DOI: 10.1016/j.ecss.2007.11.002.

Lourenço, P.M.; Silva, A.; Santos, C.D.; Miranda, A.C.; Granadeiro, J.P.; Palmeirim, J.M. (2008) - The energetic importance of night foraging for waders wintering in a temperate estuary. Acta Oecologica, 34(1):122-129. DOI: 10.1016/j.actao.2008.04.005.

Luís, P.J.P. (2006) - Macroinvertebrados de costas marinhas portuguesas: uma aplicação pedagógica. 69p., Tese de Mestrado, Universidade de Coimbra, Coimbra, Portugal. Not published.

MAOTDR (2007) - Bases para a Estratégia de Gestäo Integrada daZona Costeira Nacional. 110p., Ministério do ambiente, Ordenamento do Território e do Desenvolvimento Regional (MAOTDR), Lisboa, Portugal. ISBN 9789898097064. Available at http://www.maotdr.gov.pt/ Admin/Files/Documents/GIZC.pdf

Marques, J.C.; Pardal, M.A.; Nielsen, S.N.; Jorgensen, S.E. (1997) - Analysis of the properties of exergy and biodiversity along an estuarine gradient of eutrophication. Ecological Modelling, 102 (1997) 155-167. DOI: PII S0304-3800(97)00099-9 .

Marques, M. (2004) - Formação contínua de professores de ciências - Um contributo para uma melhor planificação e desenvolvimento. 128p., ASA Editores, Porto, Portugal. ISBN: 978-9724136066.

Marques, J.C.; Neto, J.M.; Patrício, J.; Pinto, R.; Teixeira, H.; Veríssimo, H. (2007a) - Monitoring the Mondego estuary. Anthropogenic changes and their impact on ecological quality. Preliminary results from the first assessment of the effects of the re-opening the communication between north and south arms on the eutrophication state of the system. Final Report, 87p., IMAR/INAG, Lisboa, Portugal.

Marques, S.C.; Azeiteiro, U.M.; Martinho, F.; Pardal, M.A. (2007b) - Climate variability and planktonic communities: The effect of an extreme event (severe drought) in a southern European estuary. Estuarine, Coastal and Shelf Science, 73(3-4):725-734. DOI: 10.1016/j. ecss.2007.03.010.

Martinho, F.; Leitão, R.; Neto, J.M.; Cabral, H.; Marques, J.C.; Pardal, M.A. (2007) - The use of nursery areas by juvenile fish in a temperate estuary, Portugal. Hydrobiologia, 587: 281-290. DOI: 10.1007/s10750007-0689-3
Martinho, F.; Cabral, H. N.; Azeiteiro, U.M.A.; Pardal, M.A. (2012) - Estuarine nurseries for marine fish - Connecting recruitment variability with sustainable fisheries management. Management of Environmental Quality, 23(4):414-433. DOI: 10.1108/14777831211232236.

Mora, A.M.S. (2003) - A divulgação da ciência como literatura. Editora UFRJ, Rio de Janeiro, RJ, Brasil. ISBN: 8589229025.

Nyitrai, D.; Martinho, F.; Dolbeth, M.; Baptista, J.; Pardal, M.A. (2012) -Trends in estuarine fish assemblages facing different environmental conditions: combining diversity with functional attributes. Aquatic Ecology, 46(2):201214. DOI: $10.1007 / s 10452-012-9392-1$.

Orion, N.; Hofstein, A. (1991) - The measurement of students' attitude towards scientific field trips. Science Education, 75(5):513-523. DOI: 10.1002/sce.3730750503.

Orion, N.; Hofstein, A. (1994). Factors that influence learning during a scientific field trip in a natural environment. Journal of Research in Science Teaching, 31(10):1097-1119. DOI: 10.1002/tea.3660311005.

Pardal, M.A.; Cardoso, P.G.; Sousa, J.P.; Marques, J.C.; Raffaelli, D. (2004) - Assessing environmental quality: a novel approach. Marine Ecology Progress Series, 267:1-8. Available at http://www.int-res.com/articles/ meps2004/267/m267p001.pdf.

Pardal, M.A.; Marques, J.C.; Metelo, I.; Lillebø, A.I. Flindt, M.R. (2000) - Impact of eutrophication on the life cycle, population dynamics and production of Ampithoe valida (Amphipoda) along an estuarine spatial gradient (Mondego estuary, Portugal). Marine Ecology Progress Series, 196:207-219. Available at http://www.int-res. com/articles/meps/196/m196p207.pdf

Pato, A.R.; Azeiteiro, U.M.; Gonçalves, F. (2007) Actividades prácticas na praia de São Martinho do Porto. In: F. Gonçalves, R. Pereira, U.M. Azeiteiro \& M.J. Pereira (eds), Actividades Práticas em Ciências e Educação Ambiental, pp.257-281, Ediçôes Piaget, Lisboa, Portugal. ISBN: 978-9727718559.

Patrício, J.; Marques, J.C. (2006) - Mass balanced models of the food web in three areas along a gradient of eutrophication symptoms in the south arm of the Mondego estuary (Portugal). Ecological Modelling, 197(12):21-34. 10.1016/j.ecolmodel.2006.03.008.

Pedrosa, M.A.; Mateus, A. (2000) - Perspectivas Subjacentes ao Programa de Formação no Ensino Experimental das Ciências. In: L. Dourado, M. Freitas, A. Mateus, A. Veríssimo, M.A. Pedrosa \& R. Ribeiro (eds.), Ensino Experimental das Ciências - Concepção e Concretização das acçōes de Formação 1, pp.37-48, Ministério da Educação , Lisboa, Portugal. ISBN: 972-8417446.

Ribeiro, J.L. (2005) - Factores ambientais e impactes antrópicos condicionantes das actividades tradicionais no estuário do Mondego. I Seminário Internacional sobre o sal português, pp.392-405, Instituto de História Moderna da Universidade do Porto, Porto, Portugal. Available at http://ler.letras.up.pt/uploads/ficheiros/7991.pdf

Rivet, A.E; Krajcik, J. S. (2008) - Contextualizing Instruction: Leveraging Students' Prior Knowledge and Experiences to Foster Understanding of Middle School Science. Journal of Research in Science Teaching, 45(1):79-100. DOI: 10.1002/tea.20203. 
Rocha, M.B. (2012) - O potencial didático dos textos de divulgação científica segundo professores de ciências. Revista Brasileira de Ensino de Ciência e Tecnologia (ISSN: 1982-873X), 5(2):47-68, Universidade Tecnológica Federal do Paraná, Ponta Grossa, PR, Brasil. Available at http://revistas.utfpr.edu.br/pg/index.php/rbect/article/ view/1263/847

Rosalino, L.M.; Rosalino, C. (2012) - Nature conservation from a Junior High School perspective. Journal for Nature Conservation, 20(3):153-161. DOI: 10.1016/j. jnc.2012.01.001.

Roth, W.M.; Lee, S. (2004) - Science Education as/for Participation in the Community. Science Education, 88(2):263-291. DOI: 10.1002/sce.10113

Santos, P.; Guedes, L. (1999) - Trilhas de Interpretação da Natureza. 20p., Ed. FAPAS, Porto, Portugal. ISBN: 2200014249541.

Verdelhos, T.; Neto, J.M.; Marques, J.C.; Pardal, M.A. (2005) - The effect of eutrophication abatement on the bivalve Scrobicularia plana. Estuarine, Coastal and Shelf Science 63( 1-2):261-268. DOI: 10.1016/j.ecss.2004.11.019.

Serantes, A.P. (2008) - Os equipamentos para a Educaición Ambiental en Glici: Processos de diagnose e identificatión de criterios de calidade. In: P.Á. Meira \& M.A. Torales (org.), Investigación e Formación en Educaión Ambiental: Novos escenarios e enfoques para un tempo de câmbios, pp.129-145, Centro de Extensión Universitária e Divulgación Ambiental de Galicia (CEIDA), La Coruña, Espanha. ISBN: 978-8461245192.

Veríssimo, H.; Bremner, J.; Garcia, C.m., Patrício, J.; van der Linden, P.; Marques, J.C. (2012) - Assessment of the subtidal macrobenthic community functioning of a temperate estuary following environmental restoration. Ecological Indicators, 23:312-322. DOI: 10.1016/j. ecolind.2012.04.020.

Wellington, J.; Osborne, J. (2001) - Discussion in School Science: learning science through talking. In: J. Osborne \& J. Wellington (orgs.), Language and Literacy in Science Education, pp.82-102, Buckingham, Open University Press, Maidenhead, Berkshire, UK. ISBN: 0335205992 van Wyk, E.; Breen, C.M.; Sherwill, T.; Magadlel, D. (2007) - Challenges for the relationship between science and society: developing capacity for ecosystem governance in an emerging democracy. Water Policy, 9(2):99-111. DOI: $10.2166 /$ wp.2007.138. 